\title{
MANFAAT PSIKOEDUKASI KELUARGA TERHADAP BEBAN SUBJEKTIF KELUARGA PADA KASUS KLIEN TUBERKULOSIS PARU
}

\author{
Wahyu Dini Candra Susila ${ }^{1}$, Herni Susanti ${ }^{2}$, Ice Yulia Wardani ${ }^{3}$, Eka Budiarta ${ }^{4}$ \\ ${ }^{1}$ Program Studi Magister Keperawatan Peminatan Keperawatan Jiwa, Universitas Indonesia, \\ ${ }^{2,3}$ Dosen Fakultas IImu Keperawatan Universitas Indonesia \\ ${ }^{4}$ Program Studi Spesialis Keperawatan Jiwa, Fakultas IImu Keperawatan, Universitas Indonesia \\ E-mail : wahyudinicandras@gmail.com
}

\begin{abstract}
Pulmonary tuberculosis is an infection caused by the bacterium Mycobacterium tuberculosis which attacks the lungs and is easily transmitted through sneezing, coughing, and talking. Tuberculosis causes various kinds of effects on individuals, and is also felt by families. One of the psychosocial effects experienced by families with pulmonary TB sufferers is anxiety which is a subjective burden on the family, so it needs to be fixed so that the family can support treatment optimally. Case report aims to determine the benefits of family psychoeducation to reduce the subjective burden of family anxiety. Family psychoeducation is an action given to families to improve family communication, handle problems, and improve family functions and abilities. This case report used one tuberculosis client with a care giver that experiences the subjective burden of anxiety. The results of the study showed that family psychotherapy education who used 6 sessions and 4 meetings can reduce family anxiety, (HARS score 29) to low anxiety (HARS score 16). Family psychoeducation is recommended for families with heavy subjective anxiety loads.
\end{abstract}

\section{Keyword : Family Psychoeducation, Subjective Burden, Pulmonary Tuberculosis}

\begin{abstract}
Abstrak : Tuberkulosis paru (TB paru) merupakan infeksi yang disebabkan oleh bakteri Mycobacterium tuberculosis yang menyerang paru- paru serta dengan mudah menular melalui bersin, batuk, dan berbicara. TB paru menyebabkan berbagai macam dampak pada individu, dan juga dirasakan oleh keluarga. Salah satu dampak psikososial yang dialami keluarga dengan penderita TB paru adalah kecemasan yang menjadi beban subjektif keluarga, sehingga perlu diatasi agar keluarga dapat mendukung pengobatan secara optimal. Laporan kasus bertujuan untuk mengetahui manfaat psikoedukasi keluarga untuk mengurangi beban subjektif kecemasan keluarga. Psikoedukasi keluarga merupakan tindakan yang diberikan kepada keluarga untuk meningkatkan komunikasi keluarga, menangani masalah, dan meningkatkan fungsi serta kemampuan keluarga. Laporan kasus ini menggunakan satu orang klien TB Paru dengan keluarga yang mengalami beban subjektif kecemasan. Hasil studi menunjukkan pemberian psikoedukasi keluarga menggunakan 6 sesi dan 4 kali pertemuandapat mengurangi kecemasan keluarga, (skor HARS 29) menjadi kecemasan rendah (skor HARS 16). Psikoedukasi keluarga direkomendasikan untuk keluarga dengan beban subjektif kecemasan berat.
\end{abstract}

Kata Kunci : Beban Subjektif, Psikoedukasi keluarga, TB Paru

\section{PENDAHULUAN}

Tuberkulosis paru (TB paru) merupakan infeksi yang disebabkan oleh bakteri Mycobacterium tuberculosis yang menyerang paru- paru serta dengan mudah menular melalui bersin, batuk, dan berbicara. Infeksi pada penyakitini dapat menyebar pada bagian tubuh lain seperti tulang, ginjal, meningen dan nodus limfe (WHO. 2018).

Kementerian Kesehatan Bidang Pengawasan Penyakit dan Pengelolaan Lingkungan (P2PL) pada tahun 2017 menyatakan bahwa, Insidensi TB Paru di Indonesia berada pada urutan ke 4 terbanyak di dunia. Prevalensi TB Paru di Indonesia pada tahun 2017 adalah 297 orang setiap 100.000 penduduk dengan 460.000 kasus baru setiap tahun (Kartika, 2018).

TB Paru menimbulkan dampak pada individu, dan juga dampak pada keluarga yakni merasa dijauhi oleh lingkungan, takut akan penyakit yang dialami keluarga tidak dapat sembuh, kekhawatiran terkait beban ekonomi, dan beberapa beban yang menjadi beban psikologis keluarga dengan anggota penderita TB paru. Dampak psikososial yang banyak dialami keluarga dengan penderita TB paru adalah kecemasan. Kecemasan pada keluarga sangat penting untuk diatasi karena keluarga berperan penting dalam memberikan dukungan untuk pengobatan (Depkes, 2018). Penelitian menunjukan 
bahwa dukungan keluarga sangat berpengaruh pada tingkat kepatuhan berobat penderita TB paru yang terlihat dari data mencapai 60,9\% dari 69 responden (Maulidia, 2014).

Memiliki keluarga dengan penyakit kronis menyebabkan beban terhadap anggota keluarga. Beban keluarga dapat menjadi stresor keluarga dalam merawat anggota keluarga dengan TB paru. Beban keluarga dibagi menjadi 2 yakni, beban subjektif dan beban objektif. Beban objektif merupakan beban yang berkaitan dengan permasalahan praktis selama proses perawatan anggota keluarga, seperti perubahan kegiatan sosial yang akhirnya mengganggu anggota keluarga, waktu luang dan waktu istirahat yang relatif berkurang serta pengeluaran keuangan yang bertambah. Beban subjektif merupakan beban yang berkaitan dengan reaksi emosional yang dirasakan oleh keluarga, seperti perasaan khawatir, cemas, sedih, marah, ketakutan, perasaan berasalah, dan sebagainya. Beban keluarga berdampak pada keadaan fisik maupun psikologis. Keluarga dengan anggota TB Paru memiliki perbedaan beban dengan keluarga TB paru lain, hal ini berkaitan dengan persepsi dan kemampuan masing-masing keluarga. Keluarga dengan persepsi positif dalam beban merawat anggota keluarga berpengaruh terhadap tekanan dalam situasi tersebut (Prasastyagoya, dkk, 2013).

Salah satu tindakan keluarga yang dapat dilakukan adalah psikoedukasi keluarga. Psikoedukasi keluarga merupakan pendekatan yang bersifat edukasi dan pragmatis (Stuart, 2016). Tindakan ini bertujuan untuk meningkatkan komunikasi keluarga, menangani masalah, meningkatkan fungsi dan kemampuan keluarga (Shives, 2012).

Berdasarkan uraian diatas penulis tertarik untuk melakukan studi dengan kasus berjudul "Manfaat Psikoedukasi Keluarga Terhadap Beban Subjektif Keluarga pada Kasus Klien Tuberkulosis Paru"

\section{METODE PENELITIAN}

Desain yang digunakan dalam artikel ini adalah laporan kasus yang bertujuan untuk mengetahui pengaruh psikoedukasi keluarga dalam penyelesaian masalah beban keluarga, dalam hal ini adalah beban subjektif kecemasan. Data dikumpulkan melalui wawancara dan observasi menggunakan instrumen Hamilton Rating Scale.

Subyek yang digunakan adalah satu keluarga dengan klien TB Paru dengan care giver mengalami beban subjektif kecemasan. Selanjutnya keluarga diberikan tindakan psikoedukasi keluarga. Pelaksanaan studi kasus ini dimulai pada tanggal 1 November 2019 sampai tanggal 15 November 2019 bertempat.

\section{HASIL PENELITIAN}

Hasil pengkajian pada klien dengan TB Paru didapatkan bahwa sosial support utama klien adalah istri. Dalam mengatasi masalah pada klien TB paru, care giver dalam hal ini adalah istri belum mampu mengenal masalah, memutuskan tindakan yang terbaik sesuai kebutuhan kesehatan klien, merawat klien sesuai kebutuhan, memodifikasi lingkungan dan memanfaatkan pelayanan kesehatan. Keadaan kelarga tersebut menyebabkan klien putus obat.

Care giver telah merawat klien semenjak tahun 2017, klien memiliki keluhan kecemasan karena merasa tidak nyaman dengan keadaan suami. Suami mengalami permasalahan fisik yang tidak stabil seiring manajemen kesehatan yang tidak efektif, keadaan yang tiba-tiba memburuk menambah beban kecemasan care giver. Pertemuan pertama didapatkan skor 29 menggunakan instrument HARS yang digunakan untuk mengukur kecemasan care giver, dapat ditarik kesimpulan bahwa kecemasan yang dialami care giver saat pertemuan pertama adalah cemas berat.

Berdasarkan pengkajian tersebut didiapatkan masalah pada sosial support keluarga yang membutuhkan tindakan keperawatan spesialis jiwa yakni psikoedukasi keluarga untuk memaksimalkan fungsi keluarga dan menyelesikan beban keluarga yang didapatkan beban subjektif kecemasan saat pengkajian.

Setelah merumuskan intervensi keluarga berupa psikoedukasi keluarga menggunakan enam sesi yakni mengidentifikasi masalah, mengenalkan cara merawat klien, manajemen stress keluarga, manajemen beban keluarga, memanfaatkan sistem penukung yang ada di sekitar dan 
evaluasi. Hasil evaluasi yang dilakukan selama 4 kali pertemuan didapatkan hasil setiap pertemuan dengan tindakan pertama tanggal 8 November 2019 identifikasi masalah pasien merasa cemas, tidak nyaman dengan keadaaan suami yang sakit, terkadang merasa berdebar disertai tegang di beberapa anggota tubuh, dan kesulitan konsentrasi. Data obyekif yang didapatkan yakni Nampak gelisah, tegang dengan skor HARS 29. Pertemuan kedua pada tanggal 13 November 2019 dengan tindakan cara merawat klien dengan TB Paru yang juga mengalami ansietas yang disisipkan cara mengatasi kecemasan tarik nafas dalam, hipnosis lima jari, distraksi dan spiritual menunjuukan penurunan skor HARS menjadi 20 dengan data subjektif masih merasa cemas. Data objektif pasien nampak gelisah. Pertemuan ke tiga 15 November
2019 dilakukan manajemen stres menggunakan teknik relaksasi otot progresif dan terapi pemberhentian pikiran serta manajemen beban keluarga menujukan hasil yang positif dengan skor HARS 16. Data subjektif yang didapatkan yakni penurunan kecemasan dan tegang yang dirasa di beberapa anggota tubuh berkurang. Data objektif yang di dapatkan yakni gelisah yang mencul banyak berkurang. Pertemuan ke empat 22 November 2019 dengan tindakan manajemen beban dan evaluasi menunjukkann hasil skor HARS tetap yakni 16 dengan data subjektif cemas yang masih memikirkan keadaan anggota keluarga yang TB paru. Data Objektif yang ditemukan pada keluarganampak baik dengan gelisah dan tegang yang tidak lagi ditujukkan.

Tabel 1. Perubahan Skor Beban Subjektif Keluarga: Kecemasan

\begin{tabular}{cccc}
\hline Pertemuan 1 & Pertemuan 2 & Pertemuan 3 & Pertemuan 4 \\
\hline 29 & 20 & 16 & 16 \\
\hline
\end{tabular}

\section{PEMBAHASAN}

Beban keluarga merupakan segala sesuatu yang berkaitan dengan perawatan, keuangan, psikososial yang memberatkan keluarga yang disebabkan oleh kondisi medis anggota keluarga yang sakit (Ewigman dalam Kreutzer, Deluca \& Caplan, 2011). Beban dibagi menjadi dua yaitu beban objektif dan subjektif (Stuart, 2016). Beban objektif adalah beban yang terjadi karena perlakuan khusus yang diberikan keluarga pada gejala dan perilaku pasien hinga lingkungan sosial dan konsekuensi dari gejala yang dialami anggota keluarga yang sakit. Beban subjektif keluarga sama halnya dengan beban subjektif individu, seperti stigma, kelelahan, sedih, khawatir dan tertekan (Schene, 1990).

Psikoedukasi keluarga merupakan tindakan modalitas yang dilakukan oleh professional dengan mengintegrasikan antara psikoterapi dan intervensi edukasi (Lukens \& McFarlane dalam Carthwright, 2007). Psikoedukasi keluarga merupakan suatu program perawatan kesehatan jiwa yang diberikan kepada keluarga dengan cara pemberian infromasi serta edukasi melalui komunikasi terapeutik. Terapis psikoedukasi merupakan pendekatan yang bersifat edukatif dan pragmatis (Stuart, 2016). Terapi psikoedukasi ini bertujuan untuk meningkatkan komunikasi keluarga, menangani masalah, meningkatkan fungsi dan kemampuan keluarga (Shives, 2012).Terapi psikoedukasi keluara bermanfaat untuk mengatasi beban, stres, kecemasan serta meningkatkan dukungan keluarga (Mulia, Keliat \& Wardani, 2017). Kecemasan anggota keluarga dalam merawat anggota keluarga dapat menurun menggunakan terapi psikoedukasi, kecemasan sedang menurun menjadi kecemasan sedang (Rohmi, 2015).

Kecemasan merupakan pengalaman individu yang bersifat subjektif yang sering dimanifestasikan sebagai perilaku yang disfungsional yang diartikan sebagai rasa sulit terhadap kejadian yang tidak diketahui secara pasti (Varcarolis, 2008). Psikoedukasi keluarga memberikan informasi kepada keluarga bukan mengenai penyakit saja namun memberikan kesempatan pula kepada keluarga untukmengungkapkan perasaan dan berbagi pengalaman, informasi serta mengelola kecemasan itu sendiri. Psikoedukasi keluarga mampu mengembangkan pengetahuan keluarga 
merawat klien serta mampu mengelola efek psikososial yang dialami keluarga (Jewell, et al, 2009). Hasil studi menunjukkan penurunan skor HARS dari 29 menjadi 20 setelah pertemuan ke 2 yakni diberikan materi cara merawat klien TB paru dengan ansietas. Secara detail materi yang diberikan adalah bagaimana cara merawat keluara dimulai dari pengetahuan tentang TB paru, dampak yang terjadi, pengobatan., dan juga manajemen stress yang diberikan pada klien. Pertemuan tersebut diberikan materi manajemen stres relaksasi nafas dalam, hipnosis lima jari, distraksi dan spiritual agar keluarga dapat mendampingi klien saat mengatasi stress. Pemberian manajemen stress berdampak positif juga kepada ansietas yang dirasakan keluarga. Intervensi keperawatan generalis berpengaruh positif terhadap penurunan kecemasan seseorang (Prahastowo \& Suerni, 2016).

Pertemuan ketiga memberikan hasil positif penurunan skor HARS menjadi 16 yang berarti menjadi cemas ringan pada keluarga setelah dilakukan tindakan manajemen stress menggunakan teknik relaksasi otot progresif dan terapi pemberhentian pikiran. Relaksasi otot progresif dapat mengatasi kecemasan dengan melibatkan sistem saraf simpatis dan parasimpatis, yang mana kedua sistem saraf ini saling berlawanan dan saat bekerja bersama degan periode singkat dapat memberikan respon ketenangan (Conrad \& Roth dalam Wulandari, 2015). Kombinasi antara relaksasi otot progresif dan pemberhentian pikiran juga efektif untuk menurunkan kecemasan klien (Hidayati, Keliat, \& Wardani, 2019). Pemberian manajemen beban juga diberikan pada pertemuan ini, sehingga turut menurunkan kecemasan. Manajemen beban yang dilakukan pada keluarga klien ini adalah terkait beban finansial. Klien dengan TB paru tidak mampu bekerja lagi sehingga tidak memiliki pemasukan keuangan. kebutuhan sehari-hari dan berobat ditanggung oleh anak, sehingga manajemen yang dilakukan adalah memaksimalkan uang yang diberikan oleh anak untuk kebutuhan sehari-hari, kebutuhan berobat, akses ke pelayanan kesehatan karena klien tidak memiliki kendaraan pribadi. Manajemen beban dalam psikoedukasi keluarga dapat memaksimalkan dampak positif dalam menurunkan kecemasan keluarga dalam merawat anggota dengan penyakit kronis (Dzil Kamalah, Ahsan, \& Kristianto, 2016).

Pertemuan keempat memberikan hasil yang sama terhadap skor sebelumnya yakni 16. Pemanfatan sistem pendukung dirasa kurang maksimal dalam membantu permasalahan klien dengan penyakit kronis. Kecemasan ringan yang masih dirasakan klien disebabkan karena keadaan klien yang masih dalam pengobatan dan membutuhkan usaha selama 6 bulan kedepan untuk mendampingi rutin berobat dan pengalaman naik turunnya kondisi klien.

\section{KESIMPULAN DAN SARAN}

Kesimpulan dari studi kasus ini adalah psikoedukasi keluarga efektif digunakan dalam mengurangi beban subjektif kecemasan berat. Terapi ini dilakukan selama empat kali pertemuan dengan 6 sesi terapi, dapat menurunkan skor kecemasan dari 29 menjadi skor 16 menggunakan instrument $H A R S$ yang berarti menunjukkan kecemasan yang dirasakan saat ini adalah ringan.

Berdasarkan kesimpulan studi yang dilakukan maka saran adalah sebagai berikut:

1. Bagi Institusi Pendidikan Keperawatan Diharapkan dapat lebih meningkatkan eksplorasi studi tentang psikoedukasi keluarga agar terapi dapat berkembang dengan maksimal, khususnya terkait TB paru.

2. Bagi Tenaga Kesehatan

Hendaknya perawat spesialis jiwa melakukan praktik keperawatan menggunakan terapi keluarga psikoedukasi keluarga mengingat manfaat yang didapatkan dari terapi ini. Frekuensi penggunaan psikoedukasi keluarga pada tenaga kesehatan sangat berpengaruh terhadap keterampilan.

3. Bagi Pelayanan Kesehatan

Diharapkan pelayanan keperawatan spesialis menjadi perhatian mengingat manfaat dari psikoedukasi keluarga yang merupakan kompetensi perawat spesialis jiwa.

4. Bagi Penulis

Diharapkan dapat memberikan psikoedukasi keluarga kepada keluarga pasien dalam memberikan asuhan keperawatan jiwa dan 
memperdalam manajemen materi beban.

5. Bagi Studi Selanjutnya

Diharapkan eksplorasi penelitian mengenai psikoedukasi keluarga mengingat terapi ini menjadi wadah yang lengkap untuk mengatasi permasalahan keluarga dalam merawat anggota yang sakit. Perlu diperhatikan pula terkait kecemasan anggota keluarga dengan klien

\section{DAFTAR PUSTAKA}

Jewell, T. C., Downing, D., \& McFarlane, w. r. (2009). Partnering With Families: Multiple Family Group Psychoeducation for shizophrenia. Journal of Clinical Psycology, 65(8), 868-878

Maulidia, D. 2014. Hubungan Antara Dukungan Keluarga dengan Kepatuhan Minum Obat Pada Penderita Tuberkulosis di Wilayah Ciputat Tahun 2014. Skripsi: Fakultas Kedokteran dan IImu Kesehatan Universitas Islam Negeri Syarif Hidayahtullah. Jakarta

Mulia, M., Keliat, B.A., \& Wardani, I.C. (2017). Pengaruh Terapi Kognitif Perilaku dan Terapi Psikoedukasi Keluarga terhadap Penggunaan NAPZA, Ansietas, dan Harga Diri Rendah Narapidana Remaja di lembaga Pemasyarakatan Narkotika. Tesis Fakultas IImu Keperawatan Universitas Indonesia.

Kartika, U. (2018) Indonesia peringkat 4 pasien TB terbanyak di dunia, Kompas.

Available

at:https://lifestyle.kompas.com/read /2019/03/03/1415171/Indonesia.Perin gkat.4.Pasien.TB.Terbanyak.di.Dunia .html (Accessed: 25 Desember 2019).

Dzil Kamalah, A., Ahsan, A., \& Kristianto, H. (2016). Efektivitas Psikoedukasi Keluarga Pada Caregiver Pasien Ulkus Diabetes Melitus Dalam Menurunkan Tingkat Ansietas. Jurnal IImu Keperawatan (Journal of Nursing Science), 4(2), 85-98. https://doi.org/10.21776/ub.jik.2016.0 04.02.1 penyakit kronis yang menular dikarenakan menambah beban tersendiri bagi keluarga. Penganan manajemen beban juga perlu digali kembali terkait beban iatrogenic yang disebabkan oleh sistem kesehatan khususnya rujuk berjenjang BPJS yang belum memanfatkan faskes tingkat 1 yang terdekat dengan tempat tinggal klien.

Hidayati, L., Keliat, B., \& Wardani, I. (2019). Combination of Thought Stopping Therapy and Progressive Muscle Relaxation to Reduce Anxiety. 15(IcoSIHSN), 207-210. https://doi.org/10.2991/icosihsn19.2019 .45

Prahastowo, D., \& Suerni, T. (2016). Ansietassiswayangakanmenghadapiu jiannasional Di Smp N 32 Semarang. $1-11$.

Schene, A. H. (1990). Pychiatric Epidemilogy Objective and Subjective Dimensions of Family Burden towards AN Integrative Framework for Research, 289-297

Shives, L. R (2012). Basic Concept of Psychiatric-Mental Health Nursing. Eigtt Edition. Philadelphia Wolters Kluwer Lippincot William Wilkins Healath.

Stuart, G. W. (2016). Prinsip dan Praktik Keperawatan Kesehatan Jiwa Stuart.

(Keliat B.A., \& Pasaribu, J.). Singapura: Elsevier

Rohmi, F. (2015). Pengaruh Psikoedukasi Keluarga terhadap Tingkat Kecemasan dan Kemampuan Keluarga Merawat Penderita TB di Puskesmas Sumbermanjing Wetang Kecamatan Sumbermanjing, Kabupaten Malang. Fakultas Kedokteran Universitas Brawijaya, Malang.

WHO (2018) Global tuberkulosis report 2018. France: WHO. Available at: http://www.who.int/tb/publications/glo bal_report/en/.

Wulandari, N., Wihastuti T.A., Supriati, L. (2015). Pengaruh relaksasi otot progresif $\mathrm{t} e \mathrm{r} \mathrm{h}$ a $\mathrm{d}$ a $\mathrm{p}$ penurunan 
ansietas dan peningkatan kualitas tidur pasien neurosa di wilayah kerja Puskesmas Kepanjen Kidul Kota Blitar. Jurnal Ners dan Kebidanan. Aug;2(2):163-72.
Varcarolis, E.M., Carson, V.B. \& Shoemakes, N.C. (2008). Foundation of Psychiatric Mental Health Nursing, \%th Edition, Saunders Elsevier, USA 